\title{
Karakteristik Campuran Solar dan Hasil Daur Ulang Oli Bekas sebagai Bahan Bakar Mesin Diesel
}

\author{
Ainul Ghurri ${ }^{1)}$, SPG Gunawan Tista ${ }^{1)}$ dan I Nyoman Suparta ${ }^{2)}$ \\ 1) Jurusan Teknik Mesin Universitas Udayana, Kampus Bukit Jimbaran Bali \\ ${ }^{2)}$ Jurusan Teknik Mesin Politeknik Negeri Bali \\ PS Teknik Mesin Universitas Udayana, Kampus Bukit Jimbaran 80361 \\ Telp.: 628123965206, Fax: 0361703320 \\ E-mail: a_ghurri@unud.ac.id
}

\begin{abstract}
A processing of waste lubrication oil to diesel-like fuel was conducted through precipitating, heating and blending the waste oil with $\mathrm{H}_{2} \mathrm{SO}_{4} . \mathrm{NaOH}$ is then added to neutralize the acidic of the blends. The diesel-like fuel from waste oil processing is then mixed with standard diesel fuel containing 40\%-60\%, 50\%-50\%, and 60\%-40\% diesel-like fuel and standard diesel fuel, respectively. The results showed that from the point of view of the calorific value, the content of $40 \%$ and 50\% diesel-like fuel are still within the allowable range. From the density side the pure diesel-like fuel is still within the allowable range. In related to the viscosity characteristic, the content of $40 \%$ diesel-like fuel is the upper limit to be recommended for using in common diesel engine.
\end{abstract}

Keywords: Diesel-like fuel, standard diesel fuel.

\begin{abstract}
Abstrak
Studi eksperimental pendauran ulang oli bekas menjadi bahan bakar diesel telah dilaksanakan dengan proses fisik dan kimiawi dengan membuang endapan dalam oli bekas diikuti dengan pemanasan untuk menguapkan kandungan air, serta pencampuran dengan asam sulfat $\left(\mathrm{H}_{2} \mathrm{SO}_{4}\right)$ dan natrium hidroksida (NaOH) untuk lebih lanjut menghilangkan pengotor yang ada dalam oli bekas. Hasil daur ulang kemudian dicampur dengan solar standar dengan kandungan masing-masing 40\%, 50\%, dan 60\% hasil daur ulang dan sisanya berupa solar standar. Hasil karakterisasi bahan bakar menunjukkan bahwa kandungan hasil daur ulang sebanyak 40\% volume merupakan batasan yang direkomendasikan untuk digunakan pada mesin diesel tanpa perlu melakukan modifikasi mesin.
\end{abstract}

Keywords: Bahan bakar hasil daur ulang, solar standar

\section{PENDAHULUAN}

Peningkatan konsumsi bahan bakar fosil telah sangat lama menjadi isu global untuk diatasi bersama. Penggunaan bahan bakar fosil yang sangat massif di berbagai belahan dunia menimbulkan berbagai masalah, antara lain persediaan yang semakin menipis dan mengarah ke krisis energi, efisiensi penggunaan yang rendah, serta dampak lingkungan yang ditimbulkan baik dalam pemrosesan bahan bakar maupun akibat polusi yang dihasilkan. Setiap aspek masalah tersebut juga telah mendapat perhatian baik dari sisi kebijakan serta aktivitasaktivitas riset dan akademis dalam menyiapkan alternatif dan jalan keluar permasalahan tersebut. Untuk mengurangi laju penggunaan bahan bakar fosil misalnya telah diterbitkan berbagai aturan tentang pembatasan jumlah kendaraan, penghapusan subsidi bahan bakar, serta upaya-upaya perbaikan efisiensi mesin terutama sektor transportasi yang merupakan pengguna bahan bakar yang paling besar.

Upaya pencarian energi alternatif juga telah dilakukan secara luas baik untuk mesin yang telah ada, maupun yang dilakukan bersamaan dengan desain mesin sejak awal, misalnya penggunaan bahan bakar gas, etanol dan biodiesel untuk kendaraan. Upaya pencarian ini dilakukan untuk bahan bakar cair dan gas maupun teknologi lain seperti fuel cell. Sayangnya bahan bakar alternatif ini cenderung lambat diterima masyarakat pengguna dikarenakan dianggap mahal dari sisi harga dan tingkat kesulitan yang lebih komplek dibanding mesin dan teknologi yang telah biasa digunakan.

Teknologi mesin diesel terus mengalami kemajuan pesat utamanya pada efisiensi dan aplikasinya yang paling banyak digunakan sebagai alat penggerak pada industri dan transportasi serta pembangkit listrik. Bahan bakar pada mesin diesel adalah solar yang berasal minyak bumi yang cadangannya mulai menipis sementara konsumsi solar pada mesin diesel mengalami peningkatan sehingga beberapa tahun ke depan jika solar tidak dapat dihemat hal ini akan menjadi masalah yang sangat serius. Berbagai upaya dan penelitian untuk mengurangi penggunaan bahan bakar solar dilakukan dengan perbaikan efisiensi mesin, penambahan aditif berbasis bahan nabati, dan pengembangan biodiesel dari berbagai macam tumbuhan. Secara umum 
hasilnya cukup menggembirakan namun tidak bisa dilanjutkan secara maksimal karena biaya yang mahal dan pada umumnya mesin yang digunakan masih didesain untuk bahan bakar fosil konvensional. Salah satu material alternatif yang perlu dipelajari lebih dalam adalah pengolahan ulang oli bekas baik yang berasal dari industri (pabrik) maupun oli bekas kendaraan.

Khusus untuk oli bekas jumlah produksinya di Indonesia mencapai 700 juta liter untuk setiap tahun, yang sebagian disalahgunakan dibuat menjadi oli palsu, atau dibuang sehingga mencemari lingkungan, sisanya diolah kembali sebagai oli baru atau dipakai sebagai minyak bakar pada industri kecil. Oleh karena oli (konvensional) merupakan salah satu hasil dari proses distilasi minyak mentah, oli memiliki kandungan utama senyawa hidrokarbon organic yang memiliki nilai kalor (calorific value) yang cukup tinggi, maka mendaur ulang oli bekas merupakan peluang untuk memanfaatkan energi yang tersisa dalam oli bekas setelah fungsinya sebagai pelumas selesai. Hal ini bisa meningkatkan efisiensi penggunaan dan mengurangi dampak lingkungannya.

Publikasi tentang pengolahan oli bekas menjadi bahan bakar masih sangat terbatas, barangkali itu menunjukkan masih minimnya peneliti melihat peluang ini. Arpa et.al [1] melaporkan hasil risetnya mengenai produksi bahan bakar diesel dari oli bekas dengan proses distilasi pyrolitic yang cukup rumit. Hasil penelitiannya menunjukkan bahwa bahan bakar yang lebih mendekati sifat bahan bakar diesel dihasilkan dalam jumlah 60\% dari oli bekas yang diolah. Dari beberapa aditif yang digunakan ia menyimpulkan bahwa penggunaan $\mathrm{CaO}$ sebesar $2 \%$ menghasilkan penurunan kandungan sulphur yang terbesar. Selanjutnya Arpa et.al [2] menguji bahan bakar hasil daur ulang oli bekas tersebut pada mesin diesel. Hasilnya menunjukkan bahwa bahan bakar ini tidak menunjukkan problem apapun dalam hal kinerja mesin jika dibandingkan dengan bahan bakar diesel standard. Hanya saja, kandungan sulphur dalam bahan bakar dan emisi gas buangnya melebihi standar yang diperbolehkan, sehingga ia menyarankan untuk melakukan usaha menurunkan kandungan sulphur ini. Laporan yang lebih baru disampaikan oleh Yang et.al [3], dimana karakter bahan bakar yang dihasilkan dikatakan "memuaskan” jika dibandingkan bahan bakar diesel atau biodiesel standar. Russ et.al [4] juga telah melaporkan bahwa penggunaan bahan bakar dari oli bekas menunjukkan hasil yang bagus dari segi emisi gas buang; namun ia menyarankan untuk digunakan pada mesin diesel yang tidak bergerak (misalnya mesin jenset dan mesin pertanian). Beg et.al [5] mendaur-ulang oli bekas kapal laut dan oli bekas bis \& truk menggunakan $\mathrm{H}_{2} \mathrm{SO}_{4}$ menghasilkan bahan bakar yang bisa digunakan secara langsung sebagai pengganti bahan bakar diesel berdasar batas spesifikasi Caterpillar.

Dalam penggunaannya, bahan bakar alternatif dan/atau daur ulang biasanya tidak digunakan secara langsung dalam jumlah $100 \%$ pada mesin diesel, mengingat seluruh mesin diesel yang ada didesain untuk bahan bakar diesel (di Indonesia dikenal sebagai solar). Sebagai contoh, biodiesel sampai saat ini digunakan pada kendaraan diesel komersial maksimal dengan kandungan 5\% volumetris dan yang 95\% berupa solar standar. Dalam penelitian ini, campuran antara bahan bakar solar standar dan bahan bakar hasil daur ulang oli bekas dengan prosentase $40 \%$, 50\%, dan 60\% hasil daur oli bekas diuji karakteristik bahan bakarnya apakah mampu mendekati solar standar atau tidak, sehingga bisa diprediksi kinerja mesin dan emisi gas buangnya jika digunakan dalam mesin diesel tanpa modifikasi apapun.

\section{PERALATAN PENELITIAN}

Gambar 1 menunjukkan fasilitas untuk memurnikan oli bekas menjadi bahan bakar. Bahan bakar hasil daur ulang inilah yang akan dicampur dengan solar standar untuk kemudian diuji karakteristiknya sebagai bahan bakar pada mesin diesel tanpa modifikasi mesin sama sekali.

\section{HASIL DAN PEMBAHASAN}

Hasil karakterisasi bahan bakar hasil daur ulang oli bekas, campuran $40 \%$ hasil daur ulang - 60\% solar standar, campuran 50\% hasil daur ulang - 50\% solar standar, campuran $60 \%$ hasil daur ulang - $40 \%$ solar standar dan spesifikasi bahan bakar hasil daur ulang yang dilakukan oleh Beg et.al (5) ditunjukkan dalam Tabel 1.

Sifat bahan bakar diesel yang bisa dikatakan terpenting adalah nilai kalor, viskositas dan densitasnya. Nilai kalor berimplikasi pada daya yang mampu dihasilkan dalam pembakaran. Sedangkan viskositas dan densitas berkaitan dengan karakteristik semprotan (spray characteristics) dalam ruang bakar. Densitas juga penting dalam kaitan dengan kandungan energy persatuan volumenya. Bahan bakar dengan viskositas yang rendah akan menghasilkan atomisasi yang lebih baik dan lebih cepat. 


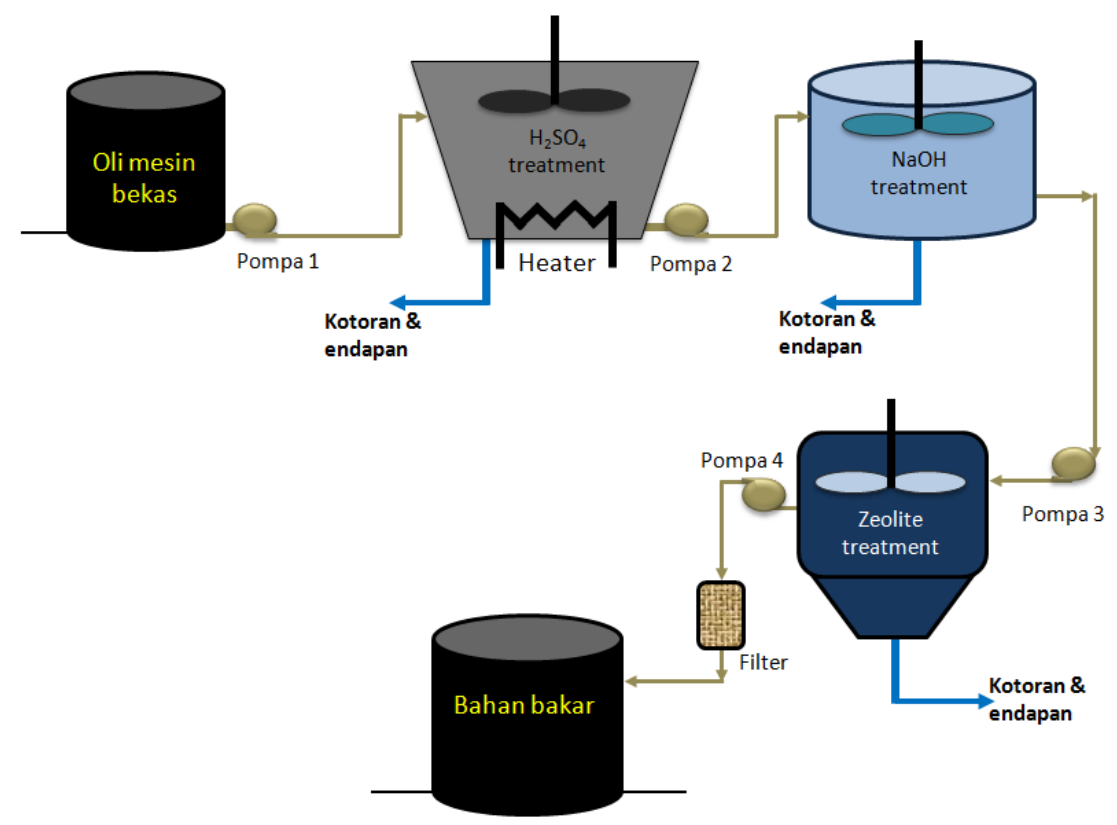

Gambar 1. Diagram alir proses pemurnian oli bekas menjadi bahan bakar

Tabel 1. Karakteristik bahan bakar hasil daur ulang dan campurannya dengan solar standar

\begin{tabular}{|c|c|c|c|c|c|c|c|c|}
\hline No & Karakteristik & Satuan & *Solar 48 & $\begin{array}{l}\text { BB hasil } \\
\text { daur } \\
\text { ulang oli } \\
\text { bekas }\end{array}$ & $\begin{array}{c}40 \% \mathrm{BB} \\
\text { hasil daur } \\
\text { ulang + } \\
\text { Solar } 48\end{array}$ & $\begin{array}{c}50 \% \text { BB } \\
\text { hasil daur } \\
\text { ulang + } \\
\text { Solar } 48\end{array}$ & $\begin{array}{c}60 \% \text { BB } \\
\text { hasil daur } \\
\text { ulang + } \\
\text { Solar } 48\end{array}$ & Beg et.al. \\
\hline 1 & $\begin{array}{l}\text { Massa jenis } \\
\text { pada suhu } 15^{\circ} \mathrm{C}\end{array}$ & $\mathrm{kg} / \mathrm{lt}$ & $\begin{array}{l}0.815- \\
0.870\end{array}$ & 0.855 & 0.821 & 0.825 & 0.829 & - \\
\hline 3 & Titik nyala & ${ }^{0} \mathrm{C}$ & $\geq 60$ & $\geq 76$ & 65 & 67 & 68 & $\geq 73$ \\
\hline 6 & Kandungan air & $\mathrm{Mg} / \mathrm{kg}$ & $\leq 500$ & - & - & - & - & - \\
\hline 8 & Partikulat & $\mathrm{Mg} / \mathrm{l}$ & - & - & - & - & - & - \\
\hline 9 & Residu karbon & \% massa & 0.10 & - & - & - & - & - \\
\hline 10 & Nilai HHV & $\mathrm{MJ} / \mathrm{kg}$ & $\sim 45.9$ & $\sim 39.736$ & 43.09 & 42.15 & 41.1 & 42.6 \\
\hline 11 & Nilai LHV & $\mathrm{MJ} / \mathrm{kg}$ & $\sim 43.0$ & $\sim 36.883$ & 40.94 & 40.04 & 39.29 & - \\
\hline
\end{tabular}

\section{*Keputusan Dirjen Migas No. 3675K/24/DJM/2006}

Hal ini merupakan kondisi yang ingin dicapai dalam mesin diesel yang pembakarannya terjadi secara spontan begitu bahan bakar siap terbakar. Dengan demikian viskositas yang lebih rendah berarti bahan bakar bisa siap terbakar lebih cepat dan ignition delay terjadi dalam waktu yang lebih singkat.

Dari Tabel 1 terlihat dari segi densitas bahan bakar hasil daur ulang memiliki densitas yang masih berada dalam rentang densitas standar yang diperbolehkan peraturan, demikian juga campurannya dengan solar standar. Dari karakteristik nilai kalornya campuran dengan kandungan hasil daur ulang $40 \%$ dan $50 \%$ bisa dikatakan masih bisa diterima karena penurunannya terhadap solar standar masih bisa diterima (misalnya, jika dibandingkan dengan biodiesel sangatlah mirip). Demikian juga jika dibandingkan hasil risel Beg et.al, nilai kalor 
bakarnya tidak jauh berbeda. Dari karakteristik viskositasnya terlihat jelas bahwa campuran $40 \%$ hasil daur ulang dan $60 \%$ solar standar memiliki viskositas yang masih berada dalam rentang yang diterima kebanyakan mesin diesel yang ada; dan juga sedikit lebih baik jika dibanding viskositas hasil Beg et.al. Sedangkan pada kandungan hasil daur ulang yang lebih tinggi sudah berada di luar spesifikasi yang diperbolehkan. Dengan demikian kandungan hasil daur ulang sebesar $40 \%$ merupakan batasan yang direkomendasikan untuk digunakan pada mesin diesel tanpa melakukan modifikasi sistem injeksi (spray)-nya.

\section{KESIMPULAN}

Studi eksperimental pendauran ulang oli bekas menjadi bahan bakar diesel telah dilaksanakan dengan proses fisik dan kimiawi dengan membuang endapan dalam oli bekas diikuti dengan pemanasan untuk menguapkan kandungan air, serta pencampuran dengan asam sulfat $\left(\mathrm{H}_{2} \mathrm{SO}_{4}\right)$ dan natrium hidroksida $(\mathrm{NaOH})$ untuk lebih lanjut menghilangkan pengotor yang ada dalam oli bekas. Hasil daur ulang kemudian dicampur dengan solar standar dengan kandungan masing-masing 40\%, $50 \%$, dan $60 \%$ hasil daur ulang dan sisanya berupa solar standar. Hasil karakterisasi bahan bakar menunjukkan bahwa kandungan hasil daur ulang sebanyak $40 \%$ volume merupakan batasan yang direkomendasikan untuk digunakan pada mesin diesel tanpa perlu melakukan modifikasi mesin.

\section{UCAPAN TERIMA KASIH}

Naskah ini merupakan bagian dari hasil penelitian di Lab. Pembakaran dan Mesin Pembakaran Dalam di PS Teknik Mesin Universitas Udayana. Penulis menyampaikan ucapan terima kasih kepada LPPM Universitas Udayana dan Fakultas Teknik Universitas Udayana, yang telah membiayai penelitian ini melalui skim Hibah Unggulan Program Studi 2016.

\section{DAFTAR PUSTAKA}

[1] Orhan Arpa, Recep Yumrutas, Ayhan Demirbas, 2010, Production of diesel-like fuel from waste engine oil by pyrolitic distillation, Applied Energy 87 (2010) 122-127, Elsevier.

[2] Orhan Arpa, Recep Yumrutaş, Zeki Argunhan, 2010, Experimental investigation of the effects of diesel-like fuel obtained from waste lubrication oil on engine performance and exhaust emission, Fuel Processing Technology 91, 1241-1249, Elsevier.
[3] Y. Yang, J.G. Brammer, M. Ouadi, J. Samanya, A. Hornung, H.M. Xu, Y. Li, 2013, Characterisation of waste derived intermediate pyrolysis oils for use as diesel engine fuels, Fuel 103, 247-257, Elsevier.

[4] Russ Winfried, Meyer-Pittroff Roland, Dobiasch Alexander, Lachenmaier-Kolch Jurgen, 2008, Usability of food industry waste oils as fuel for diesel engines, Journal of Environmental Management 86, 427-434, Elsevier.

[5] Beg R.A., Sarker, M. R. I., and Riaz Pervez, Md., 2010, Production of diesel fuel from used engine oil, International Journal of Mechanical \& Mechatronics Engineering IMMME-IJENS Vol. 10, No. 02. 